\title{
THE CONTRIBUTIONS OF THE ECONOMICS OF INFORMATION TO TWENTIETH CENTURY ECONOMICS*
}

\author{
Joseph E. Stighitz
}

In the field of economics, perhaps the most important break with the past-one that leaves open huge areas for future work-lies in the economics of information. It is now recognized that information is imperfect, obtaining information can be costly, there are important asymmetries of information, and the extent of information asymmetries is affected by actions of firms and individuals. This recognition deeply affects the understanding of wisdom inherited from the past, such as the fundamental welfare theorem and some of the basic characterization of a market economy, and provides explanations of economic and social phenomena that otherwise would be hard to understand.

\section{INTRODUCTION}

The century coming to a close has seen vast changes in economics in both ideas and methodology. Upon reflection, it is remarkable, however, how many of the seeds of advances in this century were sowed in the previous. I would argue that perhaps the most important break with the past—one that leaves open huge areas for future work-lies in the economics of information. The recognition that information is imperfect, that obtaining information can be costly, that there are important asymmetries of information, and that the extent of information asymmetries is affected by actions of firms and individuals, has had profound implications for the wisdom inherited from the past, and has provided explanations of economic and social phenomena that otherwise would be hard to understand. In this essay I wish to argue that information economics has had-directly and indirectly-a profound effect on how we think about economics today.

\section{Eighteenth and Nineteenth-Century Antecedents}

To be sure, Marshall and other nineteenth century economists talked about problems of imperfect information. But with one exception, discussions of information were obiter dicta, caveats at the end of the analysis; they were never at the center.

* The author is Professor of Economics (on leave) at Stanford University and Senior Fellow, Brookings Institution. The views expressed are those of the author and not necessarily those of any organization with which he is or has been affiliated. The author is indebted to Nadia Roumani and Noémi Giszpenc for research assistantship and to Karla Hoff and the editors for very helpful comments.

( 2000 by the President and Fellows of Harvard College and the Massachusetts Institute of Technology.

The Quarterly Journal of Economics, November 2000 
Formal analyses focused on settings in which information was, for all intents and purposes, perfect (or if not perfect, there was no modeling of the process of information acquisition). In their remarks, several of the great economists of the nineteenth (and even earlier) centuries can be seen-from the vantage point provided by information economics - to have anticipated many of its insights. Smith, Marshall, Weber, Sismondi, and Mill ${ }^{1}$ were aware of information problems, even when they did not conceive of them as such. For instance, Smith, in anticipating later discussions of adverse selection, wrote that as firms raise interest rates, the best borrowers drop out of the market. If lenders knew perfectly the risks associated with each borrower, this would matter little; each borrower would be charged an appropriate risk premium. It is because lenders do not know the risk properties perfectly that this process of adverse selection has important consequences. Marshall, too, anticipated the later efficiency wage literature, in recognizing that paying workers higher wages may increase their productivity. Implicitly, he recognized that workers were frequently not paid on the basis of tasks performed. One of the reasons for this is the inability to observe the tasks perfectlyeither the inputs or the outputs. In each case, the authors observed the consequences of information imperfections and recognized their importance, but they neither pursued the logical implications (Marshall, indeed, suggested that it would "greatly complicate" economic analysis) nor even traced the source of the observation, the phenomenon, to a problem of information.

All of these early insights of the past masters into the economics of information have been ferreted out of their writings after the development of information economics. Mainstream economic theory, embodied in the competitive general equilibrium theory formalized by Arrow [1964] and Debreu [1959], ${ }^{2}$ simply ignored these considerations. There was the hope conveyed by Marshall's dictum, "Natura non facit saltum," 3 that so long as

1. See, for instance, Smith [1776], Marshall [1928], Weber [1925], Sismondi [1814], and Mill [1848] as cited in Stiglitz [1987].

2. Debreu, in listing the key assumptions underlying his analysis, did not even include the underlying information assumptions; they were essentially taken for granted-and seemingly viewed as innocuous. Subsequent work extending Debreu's work focused on generalizations of the mathematical assumptions-but left untouched the underlying information assumptions.

3 . Literally, "Nature does not make jumps"-this was the motto on the title page of Principles of Economics and, curiously, it was also espoused by Charles Darwin, pre-"punctuated equilibrium" (see Origin of Species, Ch. 14 and Gould [1989]). Contrast this with Rosenstein-Rodan's [1984] use of the phrase "Natura facit saltum." 
information was not too imperfect, economies with "almost perfect" information would look very much like economies with perfect information, close enough that the idealized models would suffice.

\section{The Chicago School: Economics of Information as Just Another Application of General Principles}

There was also the hope that, as economic science progressed, understanding of how individuals and firms devoted resources to the acquisition of information would, and it would turn out that the same optimality properties, the Fundamental Theorems of Welfare Economics, that held for economies with perfect information would hold for economies with imperfect information (once one took these information costs into account). And it was hoped that the same kinds of tools that had provided insights into other branches of economics would work in the "economics of information." Individuals and firms would equate the marginal benefits of acquiring additional information to the marginal costs, thereby tracing out demand curves for information. Stigler's [1961] contribution on search theory showed how the calculations could be done. ${ }^{4}$ (That search was costly meant, of course, that there could be a price distribution. But Stigler did not take the next step, to analyze the nature of the equilibrium that would emerge, a point to which we will return later.)

Consider, for instance, one of the classic assumptions of traditional economics, perfect capital markets. While there was a general recognition that capital markets were not perfect, the nature, explanations, and consequences of the imperfections were far from clear. Stigler [1967], in his classic paper, provided a frontal attack on the classic imperfect capital market hypothesis, suggesting that many of the seeming imperfections could be explained by transactions costs (including information costs), that these costs were just as real as any other economic costs, implying that, once these costs were taken into account, there was no presumption that capital markets were inefficient.

Modern information economics turned these presumptions on their head: even small information costs can have large consequences, and many of the standard results_including the welfare theorems—do not hold even when there are small imperfections of

4. A number of economists also used the framework provided by statistical decision theory [Raiffa and Schlaifer 1969] to calculate the value of (or demand for) information; see, for instance, Marschak [1971] and Hurwicz [1960]. 
information. While one of the standard informal arguments for decentralization using the price system is its "information economy," information economics showed that, in general, efficient decentralization through the price system, without extensive government intervention, does not result in a constrained Pareto optimum, that is, even taking into account the costs of information.

\section{Information Imperfections and Alternative Critiques of the Standard Paradigm}

Underlying the Arrow-Debreu model were two other economic assumptions (besides those concerning information): ${ }^{5}$ there was a complete set of (state contingent) markets, and there were no problems of enforcement. Much of the theoretical literature of the last 50 years can be considered as exploring the consequences of loosening these three sets of assumptions. While this essay focuses on issues of information, it should be clear that these different strands are intimately related. For instance, there cannot be markets in contingencies that have not yet been conceived. More broadly, imperfections of knowledge (including asymmetries of information) imply that markets and contracts cannot be complete. (See Arrow [1974] and Radner [1968].) Transactions costs [Williamson 1979] provide the major alternative explanation for incomplete contracts, but it seems plausible that if information were perfect-if all contingencies could have been anticipated-all important contingencies (at least where there is the ability and desirability of transferring risk) would have been taken care of in the original contract.

By the same token, if information were perfect, contract enforcement would be a relatively simple matter and, more broadly, incentive issues would not attain the importance that they have in economics: individuals would be paid if and only if they completed the agreed-upon task in the agreed-upon manner in the agreed-upon time, and courts would be able to quickly determine whether the contract had been fulfilled.

In the real world there is not the complete set of markets (and

5. There was a fourth important assumption-that competition was perfect. The imperfections of competition that were stressed in the earlier literature [Robinson 1933; Chamberlin 1933] had to do with nonconvexities in the production technology. But even absent these, imperfections of information give rise to imperfections in competition-again showing the important links between the assumptions concerning information and the other key economic assumptions of the standard model. Still other limitations on the "perfect market" ideal, such as externalities, were emphasized by Pigou [1920]. 
especially risk and future markets) envisaged by the ArrowDebreu model. In some cases, the consequences of this incompleteness of contracts depends on the causes of the market failure; in others, they do not. Lowering transactions costs in general may, for instance, lead to a richer set of contracts if transactions costs are the primary reason for the contract limitations.

As we have already noted, Stigler argued that the imperfections in capital markets can be traced to the transactions costs associated with information. Modern information economics provided a number of alternative explanations, each of which may have considerable validity in different circumstances. These explanations not only give a more cogent explanation of the detailed nature of the market imperfections, but also a far less sanguine perspective on the imperfections themselves.

Consider, for instance, securities markets. Equity markets do a better job of risk sharing than do bond markets or loans. Yet relatively little new capital is raised through equity, and few countries have stock markets with diversified share ownership (which would presumably do better at spreading risk). Why is equity not more widely used? Information economics provides a convincing set of explanations, at least for certain circumstances. ${ }^{6}$

In economies where companies'books cannot be well auditedwhich includes most developing countries-the "costly state verification model" provides a convincing explanation for the limited use of equity. ${ }^{7}$ When insiders in a firm have more information than outsiders-a not uncommon situation-then the controlling insiders' willingness to issue equity conveys a (noisy) signal that says that on average the shares are overpriced, and the market responds by lowering the price (conversely when firms buy back shares). ${ }^{8}$ This discourages firms from issuing new shares.

Once it is recognized, however, that for whatever reason firms

6. Tax considerations may play a role as well, but the issue arises even in economies in which corporate and individual tax rates are low or in which they cannot provide an explanation for the bias against equity.

7. For a discussion of the costly state verification literature, see, e.g., Townsend [1979] and Bernanke and Gertler [1989]. The discretion that managers or controlling shareholders have to divert profits to their own benefit is one of the key issues in corporate governance. See below.

8. The theory was developed by Myers and Majluf [1984] and Greenwald, Stiglitz, and Weiss [1984], with empirical verification provided by Asquith and Mullins [1986]. Also see other articles in the Journal of Financial Economics Symposium of January-February 1986. Similar results obtain within signaling models. See Ross [1977] and Stiglitz [1982b].

These two theories are not the only information-theoretic explanations of the limited use of equity. There are also incentive-based theories (sometimes referred to as the backs-to-the-wall theories), e.g., of Jensen and Meckling [1976]. 
have limited access to (or choose to make limited use of) equitythat is, that the equity market is incomplete-then certain consequences follow. Firms resort to borrowing to raise funds; they may (and typically do) borrow enough that there is some probability of bankruptcy. Issues of what happens when bankruptcy occurs come to the fore-and determine in part how much the firm is willing to borrow. If bankruptcy imposes a cost on shareholders or managers, then firms will act in a risk-averse manner (provided that they are not too near the bankruptcy point)_explaining some of the seemingly anomalous behavior of firms (see Section III below). ${ }^{9}$

\section{Twentieth Century Antecedents}

Mr. Jourdain exclaimed in Molière's Bourgeois Gentilhomme, "Good Heavens! For more than forty years I have been speaking prose without knowing it." 10 So too for the early twentieth century economists: Hayek pointed out that the standard competitive equilibrium model could be viewed as solving a particular-and extremely important-information problem, information about scarcity. The decentralized price system led to the efficient allocation of scarce resources. No one had to know the preferences of all the individuals, or the technologies of all the firms, to ensure that resource allocations were Pareto efficient. Prices conveyed the relevant information. They were, in effect, sufficient statistics. ${ }^{11}$

Even in this domain, Hayek did not try to model how the economy processed information. Until the development of information economics, models in which economic systems had to adjust to new information were not formulated. ${ }^{12}$ The Arrow-Debreu model solved, at date 0 , the complete (state contingent) resource allocation problem.

9. When net worth becomes too low, firms may act in a risk-loving manner, a point emphasized in the literature on bank regulation. 1670.

10. Jean Baptiste Molière, Le Bourgeois Gentilhomme, Act III, Scene 4, circa

11. This information-theoretic perspective on the price system was put forward clearly by Hayek [1945]. But while arguing forcefully that the central problem of economics - of designing an efficient economic system-entailed finding "the best way of utilizing knowledge initially dispersed among all the people" [1945, p. 520], the information problem on which he focused was "how much more or less difficult to procure [particular commodities] have become relative with other things with which he is also concerned, or how much more or less urgently wanted are the alternative things he produces or uses.” [1945, p. 525].

12. This point was emphasized in Grossman and Stiglitz [1976, 1980]. Other early papers modeling market economies that are continuously adapting to new information include Grossman [1977] and Lucas [1975]. Arrow himself was aware of these limitations, as he pointed out in his presidential address to the American Economic Association [1974]. 
Besides information about scarcity, there are many other problems of information that arise in an economy. Employers want to know the productivity of their workers, their strengths and weaknesses; investors want to know the return on various assets in which they might invest; insurance companies want to know the likelihood that various people they insure might have an accident or get sick. These are examples of selection problems, where what is of concern are characteristics of the items being transacted.

Employers also want to know how hard their workers work; insurers what care their insured take to avoid an accident; lenders what risks their borrowers take. These are all examples of what are called incentive (or moral hazard) problems, and they focus on behavior.

And what is most important, as I discuss below, is that because of these other problems of information that arise in the economy, prices do not in fact solve the information problem of scarcity. The exchange process is intertwined with the process of selection over hidden characteristics and the process of providing incentives for hidden behaviors. As a result of the multiple roles that prices play, employed workers may, for instance, receive high wages while identical individuals are unemployed (the high wage rations firm demand and serves as a selection or incentive device).

In this essay I focus on information about characteristics and behavior, rather than about scarcity-because, I shall argue, of its important implications. But the twentieth century has also seen important advances in our understanding of the economics of information about scarcity. I briefly note two important sets of contributions, both dealing with situations where conventional competitive market mechanisms do not work well. One focuses on how the government can induce individuals to reveal information about their preferences for public goods $;^{13}$ the other on allocating, for instance, a particular item to the individual who values it the most through auction mechanisms. ${ }^{14}$

I do not intend to provide here a complete history of the development of information economics, but the contrast between

13. See, e.g., Groves and Ledyard [1977]. This gave rise to a huge literature on designing mechanisms for information revelation.

14. Vickrey's [1962] fundamental contribution also gave rise to a huge literature on auctions. An important branch of this literature focused explicitly on the consequences of differences in information about the item being auctioned among the participants in the auction process. For a survey of the auction literature, see Klemperer [1999]. 
some of the earlier contributions and more recent work helps to highlight how much thinking has changed. Schumpeter, like Hayek, was an Austrian working outside the Anglo-American tradition and focused on issues that today we think of as associated with information and knowledge. Both talked more in terms of evolutionary models than static ones, of incentives provided by markets to acquire new information and to make new discoveries. While underlying Hayek's analysis was a presumption that this process was efficient, or in some other ways socially desirable, no formal argument was attempted. ${ }^{15}$ Schumpeter, on the other hand, was somewhat more skeptical about the desirability of the social outcomes of the processes that he envisioned. Because his characterization of the economy was markedly different from that of Arrow and Debreu, there was no presumption that the welfare properties (the invisible hand theorem) applied to Schumpeterian competition. He also took for granted the limitations in capital markets that underpinned much of his analysis. Today, we trace some of those limitations to imperfections of information.

\section{INFORMATION ECONOMICS AS AN INTELLECTUAL REVOLUTION}

The fundamental breakthrough in the economics of information was the recognition that information was fundamentally different from other "commodities." It possesses many of the properties of a public good-its consumption is nonrivalrous, and so, even if it is possible to exclude others from enjoying the benefits of some piece of knowledge, it is socially inefficient to do so; and it is often difficult to exclude individuals from enjoying the benefits. The issue of appropriating the returns to investments in information and knowledge is thus central. Moreover, each piece of information is different from others. A piece of information

15. Indeed, more recent work has questioned the optimality of evolutionary (including Schumpeterian) processes. The development of "evolutionary economics" is, I think, one of the more important unfinished legacies of the twentieth century. The movement from equilibrium models, derived from physics, to evolutionary, dynamic models, derived more from biology and ecology, represents an important change in modes of thinking. See, e.g., Nelson and Winter [1982, 1990]. Early surveys of the evolutionary approach are van Damme [1987] and Mailath [1992]. For examples of evolutionary game theoretic literature, see Weibull [1996], Fudenberg and Levine [1998a, 1998b], Lane [1993a, 1993b], Holland [1975], and Mirowski and Somefun [2000]. For a discussion and comparison with other methods of studying the evolution of behavior, see Aoki and Feldman [1998]. Another evolutionary paper that does not use game theory is Arthur et al. [1996]. Schumpeterian competition has given rise to an equally rich literature, and it appears that except under highly special circumstances, Schumpeterian competition does not satisfy the usual optimality properties. 
cannot be purchased like a chair. An individual can look at a chair and ascertain its properties before purchasing it. But if the seller of information tells the information that he wishes to sell to the buyer (before he has bought it), there is no reason that the individual will pay for it. And while an individual may repeatedly buy, say, the same product from some store, each piece of information, by definition, has to be different from other pieces of information (otherwise, it is not new information-the buyer already knows the information). In this sense, markets for information are inherently characterized by imperfections of information concerning what is being purchased; and mechanisms like reputation-which played no role at all in traditional competitive theory-are central.

It is not only that the market for information is markedly different from the market for apples or oranges or chairs, but also that information issues are intertwined with the production and sale of traditional commodities. In traditional economics, prices convey all the relevant information (between consumers and producers, say about the scarcity value of resources). We now realize that there are a variety of other ways in which economically relevant information is conveyed, and that prices convey information other than that about scarcity. Producers and consumers realize that their actions-both individually and "collectively," e.g., through aggregate movements in prices and quantitiesconvey information, and this affects actions, so that the simple theory of consumer and producer behavior does not describe the behavior of consumers or producers in several central aspects.

A demonstration of the practical policy importance of this observation is the recent discussions about the reform of the global financial architecture: the only element of reform on which there is near universal agreement is the importance of greater revelation of information about aggregate short-term foreign debt flows and stocks, quantitative information that would simply be irrelevant in the standard Arrow-Debreu model.

The observations just made about the ways in which information and knowledge differ from conventional commodities are general: they apply both to new knowledge, about new products or processes, as well as to information, say about the characteristics of a particular investment opportunity. There have developed in the last 50 years two distinct branches of the subject-the economics of innovation and invention, focusing on what is often called knowledge, and the economics of information. Both have 
important implications for thinking about economic behavior. For instance, Schumpeterian competition, competition for new products and processes, is markedly different from the kind of price competition described by the standard competitive model. ${ }^{16} \mathrm{But}$ given the limited space of this essay, I shall focus on the two central issues on which the economics of information has focused: identifying characteristics (the selection problem) and monitoring behavior (the incentive problem).

\section{The Selection Problem}

What is now viewed as the earliest contribution to the literature on "selection" was not actually couched in those terms. ${ }^{17}$ Mirrlees [1971] asked how to design an income tax system to maximize social welfare. If the government knew everyone's ability, it should simply levy lump sum taxes on everyone. There would be no distortions. But the government does not know anyone's ability; it can observe only, say, income, and base taxes on that variable-from which it can simultaneously make inferences about individuals' abilities.

The process by which individuals reveal information about themselves through the choices that they make is today called self-selection $^{18}$ [Rothschild and Stiglitz 1976]. Mirrlees' problem is one of a large number of similar problems of one party (the government, a monopolist) designing a set of self-selection contracts (income tax schedules, pricing schedules) to maximize some objective (social welfare, firm profit). ${ }^{19}$ While the mathematical

16. Under Schumpeterian competition, there is in general imperfect competition in the product market. Schumpeterian competition focuses on the trade-offs between dynamic incentives for innovation and static inefficiency.

17. The purpose of this essay is not to provide a detailed historical account of the development of the subject. Doing so is greatly complicated by the fact that several of the most important early contributions circulated in mimeographed form for many years before publication (in some cases because several journals rejected the articles because of their unconventional nature). Thus, there is little correspondence between the date of publication and the date at which the research occurred.

18. In fact, individuals do not actually have to know their characteristics; all that is important is that individuals with different characteristics make different choices. Differences in beliefs (knowledge about themselves) are one important reason for differences in choices, but far from the only one. The literature may thus have put somewhat too much emphasis on asymmetries of information, as opposed to simply limited information.

19. While the analyses have been impressive in providing general characterization theorems (e.g., "interpretable" Euler equations), they have been less successful in providing insights into general qualitative properties, and some of these are not robust. For instance, one of the general results concerning the optimal income tax is that the marginal tax rate on the highest income individual is zero. While the political relevance of the result has always been questioned, it 
results have drawn considerable attention, the literature has also served to show the desirability of enriching the set of observablesand in doing so, has given insights, say, into both taxation and monopoly theory. For instance, if the government can observe consumption of different commodities (and at different dates), then presumably individuals should face not only an income tax schedule but nonlinear commodity tax schedules. If the government cannot observe trades among individuals, then the government is restricted to imposing linear commodity taxes-but presumably at different rates for different commodities. Ramsey's [1927] classic tax paper can be recast as an investigation into optimal taxation where the government is also unable to observe income, and so cannot impose an income tax: stated in that way, it becomes clear that it is of limited relevance for taxation in developed economies. ${ }^{20}$

Each of these results were recast in terms of Pareto optimality: given the information structure (what was observable), how could one maximize the welfare of one type of individual, given stipulated levels of others' welfare? Recast in that way, it can be interpreted as well as the problem of a monopolist who seeks to maximize profits for given reservation utilities of the consumers. In the case of a discriminating monopoly, the theory could be used, for instance, to explain random prices (e.g., sales), ${ }^{21}$ and commodity bundling [Adams and Yellen 1976].

The most difficult_-and in some sense, still not fully resolvedissues arose in analyzing competitive (or perhaps better, "market") equilibrium, in economies in which individuals have limited information, and know that they have limited information, making inferences based on available information. Akerlof's [1970] famous paper on "lemons" represented the first attempt at a partial equilibrium model, in which the market price affected the quality of the good offered, and that affected demand (since consumers rationally knew this). The resulting demand curve looked markedly different from standard demand curves, and

turns out that the result is not even robust-it depends critically on the assumption that the relative marginal productivities of different individuals are independent of factor supplies.

20. For instance, with an optimal nonlinear consumption tax, with utility functions that are separable between leisure and consumption, there should be no differential taxation of commodities. More generally, the structure of optimal commodity taxation differs markedly, depending on whether income is observable, or whether nonlinear taxation is feasible.

21. See Salop [1977]. 
Akerlof emphasized the possibility that there might in fact be little or no trade in equilibrium.

But Akerlof ignored the desire of both some sellers and buyers to acquire more information. They did not need to sit passively by making inferences about quality from price.

The literature quickly developed into two strands, one focusing on self-selection processes, the other on direct expenditures (screening, verification, search ${ }^{22}$ ) to obtain more information. In the latter case, one of the key issues is the appropriability of returns to either search or certification-which determines in large measure the incentives for search or certification. The most striking result was the existence of dual (stable) equilibria, one of which Pareto dominated the other. ${ }^{23}$ In models in which individuals differ in their ability, there may exist a "pooling equilibrium" in which no differentiation occurs. In such an equilibrium, even the more capable are better off than in the equilibrium that screens for high ability. When dual equilibria exist, more information, in this case, more information screening, seems unambiguously to lower welfare, a point to which we return later.

The self-selection literature at first seemed to bifurcate, one branch focusing on signaling by the "informed" party of the transaction (say, concerning his ability) [Spence 1974], the other on screening by the uninformed party, using self-selection mechanisms to sort [Rothschild and Stiglitz 1976]. Apart from some minor technical differences, ${ }^{24}$ however, the major distinction appeared to be in the theory of the firm. In the Rothschild-Stiglitz model, firms were profit maximizing given the actions of the other firms (i.e., they focused on Nash equilibria), but in the Spence model, there was no similar clear objective for the education authorities. There were simply a multiplicity of wage-education schedules that would "separate" out individuals, so that individuals with higher ability would obtain more education, thus allow-

22. Historically, the search literature growing out of Stigler's seminal contribution seemed to develop quite independently of the broader screening literature. In retrospect, it is clear that the two are in fact closely related: search is just the process of "screening" firms for the essential characteristic of relevance-their price.

23. See Stiglitz [1975]; also see Arrow [1973].

24. In particular, arising from Rothschild and Stiglitz employing a model with two groups, and Spence having a continuum of types. As Riley [1975] subsequently pointed out, real difficulties are encountered in the analysis of market equilibrium with a continuum of types. In some game theoretic formulations, signaling and self-selection models are differentiated by the order of moves, with the informed party moving first in signaling models, and the uninformed in screening models. 
ing an employer to make an unambiguous inference about an individual's ability on the basis of his level of education.

The self-selection/signaling literature has provided a new set of lenses through which a wide variety of issues can be viewed. We see banks signaling their trustworthiness by the size of their edifices, guarantees signaling a firm's confidence in the quality of its products, owner-managers of firms signaling their confidence that the firm is not overvalued by restricting the number of their own shares they sell. One of the key issues that firms today think about is how a particular action will be interpreted. What inferences will be made, for example, if a firm issues a different kind of security than has previously been issued, or offers a contract of a different design? The formal theory has little to say about this "out of equilibrium" behavior, but the equilibrium theories have been useful in illustrating the range of actions that can convey relevant information.

\section{Incentives and Moral Hazard}

In his path-breaking Yrjö Jahnsson lectures, Arrow [1971] delineated a second category of information problems: moral hazard, which subsequently has come to be thought of as the incentive problem. (Also see Arrow [1964].) He put the issue in the context of insurance: if individuals are insured against a risk, they have inadequate incentives to take actions to avoid the risk. If information were perfect, then the insurance contract would stipulate the actions that were to be taken, and there would be no incentive problem. But actions are, at best, imperfectly observed. Insured firms do require commercial buildings to have sprinklers (which can be readily observed), but they cannot monitor a host of other variables that might affect the likelihood of a fire, such as how frequently people smoke on the premises.

Precisely the same issue arose in the context of sharecropping-an institutional arrangement for land tenancy that is still prevalent in large parts of the world. The contract was "explained" in terms of its risk-sharing properties. The question was, what were its other consequences? Intuitively, it seemed that if workers gave landlords 50 percent (or more) of their output, their efforts would be attenuated. Cheung [1969], assuming a perfect information model, argued otherwise: the tenancy contract (implicitly) stipulated a level of effort. Stiglitz [1974] argued that the issue was essentially one of information: if information were perfect, then the optimal contract would be a wage contract (given that the 
landlord was typically far less risk averse than the workers). The worker was given a share precisely to provide him incentivesgiven that his effort could not be observed. Effort was attenuated relative to a rental contract, but workers simply could not bear the risk of a full rental contract. ${ }^{25}$

In the same paper Stiglitz laid out the two principal ways of addressing incentive issues-monitoring and incentive pay-and argued that the same issues arise in modern corporations, a theme that was developed simultaneously by Ross [1973] under the principal-agent rubric. In the subsequent quarter-century a vast literature has developed, exploring (highly restrictive) conditions under which, for instance, the optimal payment schedules might take on particularly simple forms, e.g., linearity. Yet the most profound influence has been in the recognition of the pervasiveness of principal-agent problems, the myriad ways by which people attempt to address them, and the relative benefits and shortfalls of the various methods. They occur between owners and managers and between managers and their subordinates, between the electorate and their elected officials and between elected officials and their bureaucracies.

Not surprisingly, one of the main insights in addressing these incentive issues entailed broadened payment structures (including subsidies) and combining them with monitoring. Incentive contracts focused not just on output, but on output relative to others (yardstick competition, "contests" 26 ), observing inputs so far as possible and basing pay partly on those observations, subsidizing inputs that were complements to effort (landlords might want to subsidize fertilizer), and monitoring (regulating) processes (e.g., technologies employed).

At the same time, it became clear that there were dangers in focusing incentives on easily observable variables (e.g., in education, on performance in reading and writing), because such incentive structures would divert attention away from perhaps more important but more difficult to measure outcomes, such as cognitive skills. ${ }^{27}$

25. There might be other problems with rental contracts as well: the tenant might not have capital to pay the rent at the beginning of the period, and there might be enforcement problems otherwise.

26. See, e.g., Nalebuff and Stiglitz [1983].

27. See Hannaway [1992], Milgrom and Roberts [1992], Kohn [1993], and Gibbons [1998]. 


\section{Toward Equilibrium Analysis}

Much of the early literature focused on one party (the principal-the manager vis-à-vis the workers, the owners visà-vis the managers) attempting to control, or perhaps better, affect, the behavior of the other in a desired way, or to extract information about his characteristics. Stigler analyzed how, given a price distribution, individuals decide on how much to search. But the other party does not simply react passively. Firms know that it is costly for customers to search, and will exploit that. Managers know that it is costly for shareholders to monitor them, and exploit that. At this juncture, there is a far from complete understanding of the full dynamic equilibrium, but in certain special situations, progress has been significant.

The problem of equilibrium price distributions and search has perhaps been the most thoroughly studied. Diamond [1971] showed that, contrary to Stigler's analysis, if everyone had even arbitrarily small search costs, there need not be a price distribution. In that case, the equilibrium price would be the monopoly price: the welfare losses associated with imperfections in search costs in equilibrium were completely out of proportion to the magnitude of the search costs themselves. Subsequent work showed that if individuals differed in their search costs (or, in the labor market, in the labor turnover costs), then there would be an equilibrium price distribution [Stiglitz 1985a; Salop and Stiglitz 1977, 1982; Varian 1980]. These results were important in two respects. First, they showed that even small departures from the standard model-an epsilon search cost-could dramatically change the nature of the market equilibrium. The Arrow-Debreu model was far from robust. And second, they refuted the longstanding presumption that not everyone had to be well informed for markets to work well-that as long as some, or enough, individuals were well informed, they would "arbitrage" the market.

The matter could be put another way. Once it became recognized that what people knew was endogenous, it also became clear that what they did not know was also endogenous. That is, the market and market participants might actually create noiseforcing other market participants to spend valuable resources at least partially to undo this artificially created noise. For instance, managers' differential information over outsiders is a major source of their rents; Edlin and Stiglitz [1995] ${ }^{28}$ argued not only

28. Building on related work of Shleifer and Vishny [1988, 1989]. 
that managers recognize this, but that they take actions to increase the asymmetries of information. Similarly, if all other firms were charging the same price or paying the same wage, it might pay the last firm to charge a different price or pay a different wage; equilibrium would thus be characterized by a price or wage distribution-inducing some market participants to spend scarce resources to search for the lowest price stores or highest wage firms. ${ }^{29}$

These examples show forcefully that only with the construction of equilibrium models can one fully confront the inadequacies of the Arrow-Debreu model and its core theorems on existence, optimality, and decentralization.

\section{Overturning Standard Wisdom}

Embedded in the question, what do we know today that Marshall (and others) did not know at the turn of the century, is another question: what did they think they knew that we no longer think is true? There are several dicta that, if not reversed, have become highly qualified. ${ }^{30}$

Take, for example, Marshall's famous dictum referred to earlier concerning nature abhorring discontinuities: "Natura non facit saltum." Within information economics, discontinuities abound. A particular observation may change beliefs in a discrete way. This is especially true since many observations are of discrete actions: an individual purchases insurance policy A or B, and on the basis of that purchase, beliefs change discontinuously.

Discontinuities, of course, arise whenever there are nonconvexities in the relevant sets; standard economic theory emphasized that "normally," given the importance of diminishing returns, such nonconvexities do not arise. But information is naturally associated with nonconvexities. The benefits of information increase with the scale of its production (utilization). The costs of acquiring information are "fixed" costs, and as information becomes an increasingly important part of economic activity, fixed costs would thus appear to be playing an increasing role. In a

29. Salop [1977] also showed that it might pay a monopolist to use a price, distribution to facilitate price discrimination.

30. Let me emphasize: many of the results (e.g., concerning the optimality of the market equilibrium) have been overturned on other grounds as well. I began by discussing two other important strands of modern research-incomplete markets and contracts and imperfect enforcement. These too will undermine the standard results (in ways that are quite analogous). But as we stressed earlier, information imperfections provide a key part of the explanation for these limitations. 
quite different context, Radner and Stiglitz [1984] asked the question, what is the relationship between the value of the information and the expenditure involved in acquiring that information? They showed that under a natural set of restrictions, there was a fundamental nonconvexity in the value of information. As a third example, Arnott and Stiglitz [1988] showed that indifference curves (in benefit-premium space) and opportunity sets possess none of the usual convexity properties when there is moral hazard. Hence, the mathematical restrictions that formed the basis of so much of general equilibrium analysis (see Samuelson [1947] and Debreu [1959]), as plausible as they might be in "normal" circumstances, seemed unconvincing when applied to situations where information concerns were important.

Given discontinuous change in behaviors, the possible nonexistence of market equilibrium should perhaps not have come as a surprise. Yet, the nonexistence of competitive equilibrium uncovered in Rothschild and Stiglitz [1976] goes deeper. The paper explored the extent to which market equilibrium would reveal information about differences among individuals. ${ }^{31}$ It showed that (in a highly simplified model) there could not exist a pooling equilibrium, in which the market failed to distinguish any information, simply because (under fairly weak conditions) it would always pay some firm to devise a way of inducing self-selection. At the same time, it showed that there might not exist a separating equilibrium (an equilibrium in which individuals reveal their types by their choices), because the costs of separating (in their case, the limitations on insurance purchased) might be greater than the benefits.

These were not the only results that were overturned. Perhaps the most important results in conventional competitive equilibrium theory are the fundamental theorems of welfare economics, the formalization of Adam Smith's invisible hand conjecture. Arrow [1978], building on work of Hirshleifer [1971], ${ }^{32}$ showed that in equilibrium there might be excessive incentives for gathering information-a result with profound implications

31. And it was easy to show that under natural assumptions if there were a continuum of types, there would never exist an equilibrium (see, e.g., Riley [1979]). We remain skeptical about all of the proposed "resolutions" to our seeming nonexistence paradox. See Rothschild and Stiglitz [1997].

32 . Hirshleifer's essential insight was that some of the returns to acquiring information (earlier than others) was rent acquisition; it did not actually result in more efficient resource allocation. Arrow emphasized that the additional information could reduce opportunities for risk sharing. 
for the so-called "discovery function" of stock markets. Greenwald and Stiglitz [1986] showed that the problems were more generic: whenever information is imperfect or markets (including risk markets) are incomplete - that is, essentially almost always-competitive markets are not constrained Pareto efficient. Taking into account the costs of improving information or creating markets, some individuals could, in principle, be made better off without making anyone else worse off. ${ }^{33}$ The essential intuition is that under these circumstances, actions give rise to (pecuniary) externalities, but unlike the pecuniary externalities in full competitive equilibrium models, these matter; they affect the efficiency of markets. For instance, in insurance markets with moral hazard, if individuals undertake risky actions (which cannot be monitored), then the premium will be increased; it is in no one's interest to expend the effort to exert greater care. Government interventions - in the form, say, of taxes or subsidies on commodities that might lead to greater care-will in general lead to Pareto improvements. ${ }^{34}$

These results, in turn, had profound implications for two wellestablished doctrines. First, they implied that the economy could not be efficiently decentralized. Second, along with related results by Shapiro and Stiglitz [1984], they established that the standard separation of equity and efficiency did not hold when information was imperfect. $^{35}$ Thus, both the Second Fundamental Theorem of Welfare Economics and Coase's [1960] theorem (conjecture) ${ }^{36}$ on the irrelevance of the distribution of property rights, were overturned.

33. The paper was preceded and followed by several illustrating the result in specific contexts, e.g., Stiglitz [1972, 1982a] and Newbery and Stiglitz [1984] for economies with imperfect risk markets, Greenwald and Stiglitz [1988] for search equilibrium markets, and Arnott and Stiglitz [1990] for markets with moral hazard.

34. This argument is somewhat more subtle than that sharecropping leads to less effort than individuals would exert if they did not have to share 50 percent of their output with their landlord. Such contracts can be Pareto efficient given the information structure. Our point here is that there are interventions that are welfare increasing, given the information structure.

35 . For example, in any given agency relationship, the distribution of wealth affects the scope for screening (a richer person is better able to work for low wages initially, contingent on a performance bonus once his high ability is revealed), the scope for incentives (a richer person is better able to absorb losses or post collateral, and so internalizes more of the consequences of his actions), and the problem of incomplete contracts (a richer person is better able to post a bond-as a kind of hostage - to mitigate the scope for opportunism). For a more extensive discussion of this, see Hoff [1994].

36. It should be noted that Coase himself did not believe in this formulation commonly attributed to him. There were other grounds for rejecting the hypotheses that efficiency obtained, as long as property rights were well assigned, and that distributional concerns were irrelevant, at least for efficiency, and possibly even for the determination of the nature of outcomes themselves. See, e.g., Farrell [1987]. 
The new information economics had further profound implications for economists' Weltanschauung. In standard neoclassical economics the deep properties ${ }^{37}$ of an economy-preferences and technology-determined outcomes. Not just distribution, but history and institutions did not matter. But there are natural irreversibilities associated with the creation of knowledge: history has to matter. ${ }^{38}$ Indeed, economies with the same deep properties could have markedly different equilibria. ${ }^{39}$ The new information economics not only showed that institutions mattered, and helped explain why the institutions arose and the forms they took, ${ }^{40}$ but showed why they mattered. At the same time, it dispelled a growing misconception (not unrelated to the Coase conjecture) that nonmarket institutions arose to address market failures, and that in doing so, they restored the efficiency of the economy. Arnott and Stiglitz [1991] showed that, in equilibrium, such nonmarket institutions could even exacerbate the consequences of market failure-partly because they do not directly address the broader issue of information externalities.

It was not only the basic existence and welfare theorems associated with competitive markets that information economics overturned. So too were the basic characterization theorems of a market economy with many firms. I have already called attention to three such instances: the law of the single price (a market in equilibrium is characterized by a single price) is clearly not true. Even when there are many firms, each may face a downward sloping demand curve for its product simply because of information imperfections. Market equilibrium is thus better described by models of monopolistic competition than by models of perfect competition. And the law of competitive pricing-price equals marginal cost-may also not be true, and not only as a result of the imperfections of competition to which imperfections of information give rise. ${ }^{41}$ In the presence of moral hazard problems, where

37. See Lucas and Prescott [1971] and Cooley and Prescott [1973] on structural parameters.

38. There are, of course, other reasons that "history matters": any model with irreversibilities exhibits this property. The point is that the acquisition of information almost invariably is associated with such an irreversibility.

39. A point, of course, that Darwin [1859] had made forcefully upon his visit to the different Galapagos Islands, which, with similar characteristics, possessed markedly different flora and fauna.

40. In a sense, Coase's [1937] work explaining the "firm" as an institution on the basis of transactions costs can be thought of as a precursor of this work. Another early example is Stiglitz's explanation of sharecropping discussed above.

41. Recall the remarkable result of Diamond [1971] that even arbitrarily small search costs could lead not to just a small increase in prices-but an increase to the full monopoly level. 
reputation mechanisms are required to induce "good" behavior, price must exceed marginal cost-there must be rents, costs to losing one's reputation, if individuals and firms are to behave well, and thus it is necessary for price to exceed marginal cost in an efficient market economy ${ }^{42}$ [Shapiro 1983; Shapiro and Stiglitz 1984; Klein and Leffler 1981].

One of the great advances of the mid-twentieth century was the enhanced understanding of how efficient markets operate; not everyone had to be well informed for prices in an asset market to reflect accurately the asset's true value. But not long after Fama [1970] and others explicated the full implications of that hypothesis (e.g., that it implied that stock prices move randomly), Grossman and Stiglitz [1976, 1980] showed that if information is costly, there must be an equilibrium amount of disequilibriumpersistent discrepancies between prices and "fundamental values" that provide incentives for individuals to obtain information. The only information that could be "efficiently" distributed was costless information.

Perhaps the most important result was to show that in markets with imperfect information, demand could differ from supply in equilibrium. Labor markets could be characterized by unemployment; credit markets by credit rationing; neither were phantasms. Once it became recognized that workers' productivity depends on wages, e.g., because of effects on incentives, labor turnover, or the quality of workers hired, it became clear that firms might not lower wages, even when there were workers willing to work at a lower wage, simply because doing so lowers productivity so much that the cost of labor would actually increase. The efficiency wage hypothesis ${ }^{43}$ thus provided an explanation for persistent unemployment-and for small differ-

42. While showing that price must exceed marginal cost to elicit "good" behavior, Shapiro [1983] also shows that there are circumstances (a large number of potential entrants capable of producing a given quality that is offered in the market) where the losses that a firm obtained before its reputation was established would just offset the profits it obtained after establishing a reputation, so that over the firm's entire life the present discounted value of rents would be zero.

43. The notion that productivity depends on wages (the efficiency wage hypothesis) has a long history - dating at least back to Marshall's Principles of Economics, as already noted ["highly paid labour is generally efficient and therefore not dear labour; a fact which though it is more full of hope for the future of the human race than any other that is known to us, will be found to exercise a very complicating influence on the theory of distribution"]. Earlier discussions (e.g., Leibenstein [1957]) focused on nutritional effects. Information economics showed how such arguments also applied to more developed countries. More recent discussions have focused on morale effects (e.g., in Stiglitz's early discussion of discrimination and Akerlof and Yellen [1986]). 
ences in productivity being translated into large differences in wages (those with slightly higher productivity being selected into those jobs in which efficiency wages were paid). Stiglitz and Weiss [1981] and Keeton [1979] showed that similar reasoning could explain credit rationing.

This list of standard results that have been overturned is not meant to be exhaustive. But the point should be clear: much of what economists believed-what they thought to be true on the basis of research and analysis over almost a century-turned out not to be robust to considerations of even slight imperfections of information.

As the old saw has it, it isn't what you don't know that matters so much, but what you know that isn't true! Information economics has made us realize that much of standard economics is based on foundations resting on quicksand.

\section{APPLiCATIONS}

Information economics has had a wide variety of empirical applications. Some of the work has tested particular implications of the theory in particular contexts. For example, the prediction noted earlier that as a result of "adverse signaling," when firms issue new shares the share price falls, and when they buy back shares the share price rises, has been confirmed by numerous studies. One of the problems with testing the theory is that there are often alternative hypotheses which are also consistent with the conclusions. In the instance just cited, if securities are imperfect substitutes for each other, each will face a downward sloping demand curve, and, accordingly, an increase in the supply (or even the announcement of a future increase in the supply) of shares should lead to a fall in the price of shares. Thus, tests of the information-theoretic hypotheses often rest on differentiating responses on the basis of differences in information. The theory predicts especially large price responses when (presumably informed) insiders decide to sell their shares.

Similarly, information (screening and signaling models) explains why those who remain in school longer receive higher salaries-but so do the standard human capital models and, indeed, both undoubtedly play a role. But there are aspects of the returns to education that seem consistent with the informationtheoretic perspectives and are hard (but not impossible) to reconcile with the human capital perspective. For instance, that 
an individual graduates might seem to convey information-and thus yield a return-that is beyond the increase in productivity that is associated with the learning that occurs each year; and the return to the fourth year of high school or college (graduation) does appear significantly greater than the returns to previous years. To be sure, it is possible that in the fourth year, all the information that has been put into the student "gels" together and finally makes sense; there is a nonconvexity to the production process-but the information-theoretic explanations seem far more plausible. By the same token, human capital theories would suggest that the relevance of what the student studies to his actual job should matter a great deal; in practice, it does not seem to. ${ }^{44}$

The central concepts of moral hazard and adverse selection have in a short span of years become standard in policy discussions. A major criticism of the IMF bailouts in East Asia and elsewhere in the recent global financial crisis focused on the "moral hazard problem." The bailout, combined with the support of exchange rates, attenuated incentives for lenders to engage in due diligence in their lending and for borrowers to have adequate cover for risks of exchange rate changes.

Both adverse selection and moral hazard were central in the debates over health care reform that began in 1993-and the paucity of empirical information on the magnitude of each played an important role in some of the resulting policy impasses. Consider, for instance, the debate about medical savings accounts (MSAs). These were designed to encourage individuals to buy insurance policies with larger deductibles and copayments, thereby reducing the magnitude of the distortions arising from moral hazard. But critics worried that those with lower probabilities of needing medical care would more likely avail themselves of MSAs, setting in motion a process of adverse selection. Those who chose to buy policies with larger deductibles and copayments might indeed face lower total medical costs, not because of improved incentives, but because of the impetus that the MSAs provided for "cream skimming."

In the following paragraphs, I discuss three specific issues that have been extensively analyzed from the informationtheoretic perspective.

44. For a more extensive discussion of these issues, see Weiss [1995]. 


\section{Sharecropping and the Theory of Rural Organization in Developing Countries}

One of the central aspects of less developed countries is that markets work less efficiently, including "markets for information." One would expect information problems to be more pervasive, and their consequences more noticeable; and, indeed, over the past fifteen years, an entire theory of rural organization, buttressed by a wealth of empirical studies, has developed to help explain, on the basis of information imperfections, a variety of institutions and market imperfections widely observed in developing countries. ${ }^{45}$ Earlier, we referred to the alternative explanations of sharecropping. One of the clear implications of the informationtheoretic models (as opposed to those, such as Cheung's, that emphasized risk sharing with good monitoring) is that productivity on land under share tenancy should be lower. By contrast, under the assumption of perfect monitoring, not only should output per (quality adjusted) acre be the same, but so should inputs. Empirical studies have confirmed the informationtheoretic models, with both inputs and outputs markedly different across tenancy arrangements (and in the ways predicted by the theory). ${ }^{46}$

Other aspects of behavior within the rural sector of developing countries that can be explained by information-theoretic models include the interlinkage of transactions in labor, credit, and land markets and numerous features of credit markets, most particularly, the success of micro-credit schemes based on peermonitoring. ${ }^{47}$

\section{Capital Constraints and the Theory of the Firm}

Earlier, we noted that information economics can be used to explain credit rationing and the limitations in the use of equity finance. Empirical research [Mayer 1990] confirms the relative unimportance of equity as a source of new finance for firms, even in countries with seemingly developed capital markets. ${ }^{48}$

45. For a more extensive discussion see the papers collected together in Hoff, Braverman, and Stiglitz [1993] and the literature cited there.

46. See, for instance, Shaban [1987] who concludes his careful econometric study with the conclusion that "the sizeable differences that are found in the case of sharecroppers are caused by the form of contractual arrangements ..."

47. The theory of peer monitoring is developed in Arnott and Stiglitz [1991]. There has now developed an extensive empirical literature; see, e.g., Morduch [1998], Pitt and Khandker [1998a, 1998b], and Zaman [1998].

48. As always, there may be alternative explanations, e.g., preferential tax treatment of debt. However, that little new finance is raised by equity in countries 
Over the past two decades, a large body of theoretical and empirical research has traced out the implications of these financial market constraints for the behavior of firms, most notably with respect to investment, but also with respect to other decisions. In particular, with well-functioning capital markets, risks will be widely diversified, so that firms will act in a risk-neutral manner; but with financial market limitations, especially in equity markets, firms will act in a risk-averse manner. ${ }^{49}$ The main thrust of this research has been to argue that investment will be affected by financial variables, such as firm cash flow and net worth, which in a standard neoclassical model would not matter. In those models, only the returns to the investment relative to the cost of capital matters. ${ }^{50}$ Note that even in Stigler's interpretation of capital market imperfections, these financial variables do not matter; transaction costs (including information costs) affect only the true "cost of capital."

The challenge in the empirical research was to separate out changes in financial variables from changes in either the cost of capital or investment opportunities. Over the past decade, a large number of clever ways by which this can be done have been devised. (For a survey, see Hubbard [1998].) The studies identify firms that are more likely to be credit constrained (e.g., small firms, firms paying out low dividends, firms that do not have access to the commercial paper market). The overwhelming evidence is that for such firms, financial variables do matter. For instance, adverse changes to cash flow and net worth caused by tax law changes ${ }^{51}$ (that affect average but not marginal tax rates)

with markedly different tax structures, that the fraction raised by new equity does not seem very sensitive to changes in tax laws, and that, in the United States, the tax advantages of debt are limited (and in some periods, negative) as a result of the preferential tax treatment of capital gains, suggest that tax considerations have not been dominant.

49. When firms have to rely on debt finance, they face a probability of bankruptcy. If there are significant costs of bankruptcy, if firms maximize expected (present discounted) profits net of (expected) bankruptcy costs, they still will normally act in a risk-averse manner-although if net worth becomes sufficiently low, they may behave in a risk-loving manner. Principal-agent models of the firm also can explain risk-averse behavior of the firm. See Greenwald and Stiglitz [1990, 1993].

50. See, for instance, Hall and Jorgenson [1967], which was based on Modigliani and Miller's [1958] analysis showing that financial structure does not matter under perfect information, so long as there are no bankruptcy costs. Interestingly, empirical work prior to Modigliani and Miller strongly suggested the importance of these financial variables. See Meyer and Kuh [1957]. It was misguided theories, not the empirical evidence, that led to the omission of these variables in the research of the next two decades.

51. A particularly telling experiment is that provided by the undistributed profits tax of 1936-1937. See Calomiris and Hubbard [1990]. 
or changes in the circumstances in other activities of the firm (e.g., in the profits from oil in firms that have nonoil-related activities ${ }^{52}$ ) do affect investment significantly.

The theory also predicts that the effect of these financial variables differs across types of investment, with investments in R\&D being particularly sensitive, ${ }^{53}$ and investments in inventories moving procyclically rather than countercyclically, as bufferstock models predict. ${ }^{54}$ Empirical studies confirm these predictions. ${ }^{55}$ Other aspects of firm behavior, ${ }^{56}$ such as pricing decisions, will also be affected. For instance, Greenwald and Stiglitz [1989] show how risk-averse behavior can explain wage and price rigidities. ${ }^{57}$ Phelps and Winter's [1970] prediction that capitalconstrained firms will invest less in increasing market share when facing financial constraints-leading to higher markupshas been confirmed by Chevalier and Scharfstein $[1995,1996] .{ }^{58}$

52. See Lamont [1997].

53. By contrast, neoclassical theory suggests that long-term investments should be particularly insensitive to changes in short-term interest rates. The high sensitivity of R\&D to financial variables appears even for industries like automobiles where one might have hypothesized relatively good access to capital. See Greenwald, Salinger, and Stiglitz [1990] and Hall [1992].

54 . In the standard theory, the opportunity cost of resources (underemployed workers and machines) is low in a recession, so that unless storage costs are very high, it pays firms to smooth production, putting goods into inventory in downturns and taking them out of inventory in upturns. In cash-constrained firms, the depletion of inventories is a relatively low cost way of obtaining needed liquidity.

55. While for some types of inventories, e.g., those directly associated with sales and production, procyclicality would have been anticipated, the procyclical nature of inventories is more general. See, for instance, Carpenter, Fazzari, and Petersen [1994] and the studies cited in Hubbard [1998]. Kashyap, Lamont, and Stein [1994] show that inventory behavior of firms facing liquidity constraints differs in the predicted way from those that do not. For a broader discussion of inventory behavior, see Blinder and Maccini [1991].

56. Still another aspect of firm behavior that is consistent with imperfect information models is the high level of retentions associated with windfall gains, although there are alternative specific structures that are in accord with the observations. See Blanchard, Lopez-de-Silanes, and Shleifer [1994] and Fazzari, Hubbard, and Petersen [1988a].

A variety of studies have analyzed how financial constraints should affect firm employment policies (e.g., decisions concerning hours, layoffs, and new hires), and these predictions have been broadly confirmed. See, e.g., Greenwald and Stiglitz [1987, 1995].

57. They show, in particular, that it provides a better explanation of several aspects of wage and price rigidities than do alternative theories such as menu-cost theories [Mankiw 1985; Akerlof and Yellen 1985]. Other information-theoretic models (using search theory) have provided alternative explanations of wage and price rigidities, an alternative explanation of kinks in demand and supply curve to that provided by industrial organization theories based on asymmetries in responses to competitors' increasing and decreasing prices. See, e.g., Stiglitz [1987b].

58. Similarly, changes in a firm's liquidity position, as a result of, say, a leveraged buyout, lead to increased markups. See Phillips [1995]. 
That firms are financially constrained, and that those financial constraints affect firm behavior, has, in turn, important policy implications. Average tax rates, not just marginal tax rates, affect firm behavior, as predicted by the theory [Fazzari, Hubbard, and Petersen 1988b]. Contractionary monetary policy has disproportionately large effects on financially constrained firms, with the magnitudes of the effects greater than can be explained by changes in interest rates alone. ${ }^{59}$ In the recent East Asia crisis, there is considerable evidence that high interest rates had large impacts on firm supply, explaining in part why exports did not respond to the marked depreciations in the exchange rate to the extent predicted. ${ }^{60}$

\section{Governance}

The recent global crisis also brought to the fore concerns about transparency - another name for information. Lack of transparency was blamed not only for misleading investors into putting excessive funds into the region, but also for the subsequent flight of funds from the region. Lack of information implied that investors could not discriminate effectively among borrowers, and so rationed credit to all. ${ }^{61}$ Although subsequent research suggested that the motivations for these charges may not, themselves, have been totally transparent and that transparency was not the main source of the problem, ${ }^{62}$ the public discussion did focus attention more broadly on issues of governance and information. Here, I have time only to consider corporate governance.

Marshall, in his 1897 retrospective on economics at the end of

59. There is a large theoretical and empirical literature on the credit availability channel for monetary policy. See, e.g., Wojnilower [1980], Blinder and Stiglitz [1983], Gertler and Hubbard [1988], King and Levine [1993], Gertler and Gilchrist [1994], Bernanke and Gertler [1995], Gilchrist and Zakrajsek [1995], Oliner and Rudebusch [1996], and Kashyap and Stein [2000]. That many firms are not credit constrained, and that such firms are affected by interest rate and exchange rate changes, is not inconsistent with the view that credit availability itself has, at times, a direct impact, especially since the effects of monetary policy are often concentrated in those parts of the economy that face financial constraints.

60. See World Bank [1998, 1999].

61. Note that apparently many, if not most, of the creditors refused to roll over loans at any interest rate- that is, there appeared to be credit rationing. There were simply not discussions about the interest rate at which funds would be extended.

62. Some suggested that there were political motivations for these allegations-to shift blame from the creditors who seemed, in some cases at least, not to have exercised due diligence, to the debtors, and from the international agencies who had pushed premature capital account liberalization to the developing countries. See, for instance, Rodrik and Velasco [1999] and Furman and Stiglitz [1999]. 
the last century, focused on corporate governance as one of the main "unexplained" issues to be addressed by economists in the next century. In what is sometimes called the "engineering economics" of the first two-thirds of this century, all firms did was (to paraphrase Joan Robinson's description) to look up in the book of blueprints the technology (and other actions) that maximized market value. Managers were engineers-not really decision makers trying to figure out, in the presence of highly imperfect information, what actions were most likely to maximize the firm's value (or their own welfare). Workers did not have to be motivated-they agreed to perform certain actions in return for a certain pay. All that makes life interesting and difficult was omitted. Marshall intuitively recognized that there was something wrong with this story and, in particular, there was something different between decision making in a firm owned by a single individual and that in a joint stock company. He would have been aware of the numerous failures of joint stock companies over the preceding two centuries in Europe. Marshall, too, intuitively recognized the principal-agent problem-managers' interests and shareholders' interests did not coincide. On the other hand, Marshall's resolution of this quandary, that managers seemed to be "well behaved" in spite of a seeming absence of explicit incentives, attributed the success of the British corporation in no small measure to a combination of British breeding and upbringing. That explanation is hardly acceptable today.

While early in the century, Berle and Means [1933] heightened awareness of the problems arising from the separation of ownership and control, it was only with the development of information economics that clarity was brought to the range of issues. ${ }^{63}$ Lack of information and the economies of specialization (themselves related to the nonconvexities associated with information) force owners (shareholders) to delegate responsibility for gathering information and making decisions to managers. But that same lack of information gives managers discretion to act in their own interests-as opposed to the interests of the shareholders. Managerial incentive schemes are designed to align interests, but do so imperfectly. Other checks are provided by lenders, in particular banks, and by the "market for managers" (takeovers). But both of these have important limitations too. ${ }^{64}$ Legal institu-

63. See, e.g., Stiglitz [1985b].

64. See, for instance, Grossman and Hart [1996]. The issue of corporate governance can be viewed more broadly as embracing conflicts of interests among 
tions ${ }^{65}$-from reporting requirements to strong fraud laws to laws to protect minority shareholders from the majority-are all essential parts of a broad system of corporate governance that, while it may result in outcomes that depart significantly from the simple "ideals" of value-maximizing firms, works reasonably well in the better performing industrial economies. Within these economies, two alternative models are found: one in which stakeholders other than shareholders have well-defined rights (and obligations) and all residual control and income is vested in shareholders, and the other "stakeholder" model in which outcomes are determined as a result of a complex bargaining process. In the United States, lenders (banks) are starkly demarcated from shareholders, while in Japan and Germany, with various forms of universal banks, the two are more mixed ${ }^{66}$-raising the possibility of a closer congruence of interests, but also the possibility of greater conflicts of interests. Both models have had their advocates, with the weight of opinion shifting in favor of the universal banks in Japan's heyday in the 1980s, and since then against it.

But while there is a debate about the preferable system of corporate governance, there is little debate that weak corporate governance can lead to real problems-the problems in the economies in transition have been attributed in no small measure to inadequacies in the legal infrastructure underlying corporate governance, leading managers to have incentives directed more at stripping assets and "tunneling" than in creating wealth. ${ }^{67}$

\section{CONCLUdING REMARKS}

Hayek was correct in arguing that the central problem of economics was a problem of knowledge or information: "the

all the stakeholders of the firms, e.g., different classes of providers of capital. Issues of corporate governance are, of course, not solely related to problems of information; incomplete contracts (which we have repeatedly noted are at least partly due to imperfections of information) provide an important source of managerial discretion; and the public good nature of management-all shareholders benefit if the returns to the firm increase-provides an explanation for some of the problems facing diverse share ownership.

65. See, for instance, La Porta et al. [1998].

66. See, for instance, Kester [1993].

67. See, for instance, Black, Kraakman, and Tarassova [2000], Aghion and Blanchard [1996], Weiss and Nikitin [1998], World Bank [1996], and Dyck [2000].

A huge theoretical and empirical literature has developed over the past two decades on the issues of corporate governance. In addition to the works already cited, see, for instance, European Corporate Governance Network [1997], American Law Institute [1994], the Cadbury Commission [1992], Fama and Jensen [1983], Jensen [1991], Macey [1998], Shleifer and Vishny [1997, 1998], Williamson [1985], and Zingales [1994]. 
utilization of knowledge not given to anyone in its totality" [1945, p. 520]. But he, like so many of the nineteenth and early twentieth century economists, focused too narrowly on the admittedly central problem of information about scarcity. And the mainstream of economics focused on how the price system solved a once-and-for-all resource allocation problem, not how, or how well, the market system responded to a continual barrage of new information. I have argued here that, beyond a wealth of specific results, information economics has changed the way we think.

- The key question is one of dynamics: how the economy adapts to new information, creates new knowledge, and how that knowledge is disseminated, absorbed, and used throughout the economy.

- There are many dimensions to knowledge and information beyond scarcity-knowledge about new products and processes; information about individual's abilities and performance, or about the likely returns to different securities.

- Information that is relevant to economic actors is conveyed not just by prices, but by a host of other variablesincluding actions of individuals and firms, and quantities (e.g., inventories).

- The information that is conveyed by prices is not just related to scarcity.

- Individuals and firms recognize both that prices convey information other than about scarcity (e.g., about quality) and that their own actions convey information to others. This affects their behavior in a myriad of ways-but most important for standard economic theory, their behavior in many circumstances may not be well described by the standard theory of the firm and household behavior.

- Correspondingly, many of the standard results do not, in general, hold: the market economy is not in general constrained Pareto efficient; the distribution of income matters, e.g., for whether the economy is Pareto efficient, so that issues of distribution and efficiency cannot be separated; equilibrium may be characterized by supply differing from demand (e.g., credit rationing, unemployment). Moreover, while much of conventional economics was developed under the hypothesis of convexity of production sets and preferences (based on diminishing returns), nonconvexities are pervasive in information economics. 
- But information economics has gone beyond simply destroying old results; it has provided explanations for phenomena and institutions for which the standard theory provides no explanation-and in some cases are even hard to reconcile with standard perfect information models.

- Market forces also create the incentive to make noise, which induces price dispersions, or which induces managers to undertake activities that obfuscate information (thereby increasing their own rents).

Let me emphasize a point I made in the introduction: many of the results (such as the nonoptimality of the market equilibrium) can be explained in other ways, e.g., as a result of incomplete contracts or imperfect enforcement. Information economics is one of several departures from the standard paradigm that have provided important insights-views of the world that are, ironically, often more consonant with those of Marshall than with the competitive equilibrium models that dominated economic theory during much of this and the preceding century. But I would go further: at least part of the force of these other limitations arises from imperfections of information. If individuals could be paid on the basis of piece rates-if output (including quality) could be costlessly observed-then efficiency wage theory (regardless of how derived) would no longer be of much concern. If all the important contingencies could be foreseen, then even if contracts were incomplete, the consequences would be far less serious.

These, and related, results of information economics show forcefully that the long-standing hypothesis that economies with imperfect information would be similar to economies with perfect information-at least so long as the degree of information imperfection was not too large-has no theoretical basis. And the analysis shows clearly that the economics of information cannot be approached as just another special branch of economics, like agriculture, where economists look at the special nature of the supply and demand functions in the "information sector."

Some have worried that in departing from the ideal of perfect information, a Pandora's box has been opened up. Since results often seem to depend, so sensitively, on the particular information assumptions employed, how are we to know what is the correct model? But the standard models have themselves made a particular set of informational assumptions - that information is perfect, or at least fixed-a set of informational assumptions which is fundamentally indefensible. Equally importantly, information 
economics has shown that results using that particular assumption themselves are far from robust.

The complexity of the subject has resulted in many of the models being highly parameterized-using assumptions (like quadratic or constant absolute risk aversion utility functions) that, while mathematically tractable, are known to have properties that are inconsistent with observed behavior.

The information economics that has developed over the past quarter of a century has provided a rich agenda for the next. Some of the advances will be technical in nature, going beyond the particular parameterizations, toward more general theories. Some of the advances will entail arriving at a broader consensus concerning what particular information assumptions are appropriate in particular circumstances, hopefully based on more empirical research. Some of the advances will entail new applications, showing the role that information considerations play in explaining a broader array of institutions and behavior. Some will entail an integration of economics with other social sciences-with psychology, on, for instance, how individuals process information, form expectations, and select among possible signals; and with sociology, on, for instance, the creation of social knowledge and signaling conventions. But perhaps the most important advances will be in two areas in which only limited progress has been made so far: on dynamics and on organizations, on how and how well organizations and societies absorb new information, learn, adapt their behavior, and even their structures; and how different economic and organizational designs affect the ability to create, transmit, absorb, and use knowledge and information.

StANFoRd University AND THE BRoOKINGS Institution

\section{REFERENCES}

Adams, William James, and Janet Yellen, "Commodity Bundling and the Burden of Monopoly," Quarterly Journal of Economics XC (1976), 475-498.

Aghion, Philippe, and Olivier Blanchard, "On Insider Privatization," European Economic Review, XL (1996), 759-766.

Akerlof, George A., "The Market for 'Lemons': Quality Uncertainty and the Market Mechanism," Quarterly Journal of Economics, LXXXIV (1970), 488-500.

Akerlof, G., and J. Yellen, "A Near-Rational Model of the Business Cycle, with Wage and Price Inertia," Quarterly Journal of Economics, C (1985). Supplement, 823-838.

Akerlof, G., and J. Yellen, eds., Efficiency Wage Models of the Labor Market (New York: Cambridge University Press, 1986).

American Law Institute, Principles of Corporate Governance: Analysis and Recommendations (St. Paul, MN: American Law Institute Publishers, 1994).

Aoki, K., and M. Feldman, "Theoretical Aspects of the Evolution of Human Social Behavior," Santa Fe Institute Working Paper No. 98-11-099, 1998. 
Arnott, R., and J. E. Stiglitz, "The Basic Analytics of Moral Hazard," Scandinavian Journal of Economics, XC (1988), 383-413.

Arnott, R., and J. E. Stiglitz, "The Welfare Economics of Moral Hazard," in $\mathrm{H}$. Louberge, ed. Risk Information and Insurance: Essays in the Memory of Karl H. Borch (Boston, Dordrecht, and London: Kluwer Academic Publishers: 1990), pp. 91-122.

Arnott, R., and J. E. Stiglitz, "Moral Hazard and Nonmarket Institutions: Dysfunctional Crowding Out after Monitoring," American Economic Review, LXXXI (1991), 179-190.

Arrow, Kenneth, "The Role of Securities in the Optimal Allocation of Risk Bearing," Review of Economic Studies, XXXI (1964), 91-96.

_ Essays in the Theory of Risk-Bearing (Chicago, IL: Markham Publishing Co., 1971); chapters 2 and 3 are the 1963 Helsinki lectures.

"Higher Education as a Filter," Journal of Public Economics, II (1973), 193.

- "Limited Knowledge and Economic Analysis," American Economic Review, LXIV (1974), 1-10.

"Risk Allocation and Information: Some Recent Theoretical Developments," Geneva Papers on Risk and Insurance, No. 8, 1978.

Arthur, W. B., J. H. Holland, B. LeBaron, R. G. Palmer, and P. J. Taylor, "Asset Pricing under Endogenou Expectations in an Artificial Stock Market," in The Economy as an Evolving Complex System II, Santa Fe Institute Series in the Sciences of Complexity. Santa Fe Institute Working Paper No. 96-12-093, 1996.

Asquith, Paul, and David W. Mullins, Jr., "Equity Issues and Offering Dilution,” Journal of Financial Economics, XV (1986), 61-89.

Berle, A. A., and G. C. Means, The Modern Corporation and Private Property (New York: Macmillan, 1933).

Bernanke, B., and M. Gertler, "Agency Costs, Net Worth, and Business Fluctuations," American Economic Review, LXXIX (1989), 14-31.

Bernanke, B., and M. Gertler, "Inside the Black Box: The Credit Channel of Monetary Policy Transmission,” Journal of Economic Perspectives, IX (1995), $27-48$.

Black, Bernard, R., Kraakman, and A. Tarassova, "Russian Privatization and Corporate Governance: What Went Wrong?" Stanford Law Review, LII (2000), forthcoming. Available from the Social Science Research Network electronic library at: http://papers.ssrn.com/paper.taf?abstract_id=181348.

Blanchard, O., F. Lopez-de-Silanes, and A. Shleifer, "What Do Firms Do with Cash Windfalls?” Journal of Financial Economics, XXXVI (1994), 337-360.

Blinder, Alan, and Louis Maccini, "Taking Stock: A Critical Assessment of Recent Research on Inventories," Journal of Economic Perspectives, V (1991), 73-96.

Blinder, Alan, and J. E. Stiglitz, "Money, Credit Constraints and Economic Activity,"American Economic Review, LXXIII (1983), 297-302.

Cadbury Commission, "The Financial Aspects of Corporate Governance" (London: Professional Publishing Ltd., 1992).

Calomiris, Charles W., and R. Glenn Hubbard, "Firm Heterogeneity, Internal Finance, and 'Credit Rationing," Economic Journal, C (1990), 90-104.

Carpenter, R., S. Fazzari, and B. Petersen, "Inventory Investment, InternalFinance Fluctuations, and the Business Cycle," Brookings Papers on Economic Activity, 2 (1994), 75-122.

Chamberlin, Edward H., The Theory of Monopolistic Competition (Cambridge, MA: Harvard University Press, 1933).

Cheung, Steven, The Theory of Share Tenancy (Chicago, IL: University of Chicago Press, 1969).

Chevalier, Judith, and David Scharfstein, "Liquidity Constraints and the Cyclical Behavior of Markups," American Economic Review, LXXXV (1995), 390-396.

Chevalier, Judith, and David Scharfstein, "Capital-Market Imperfections and Countercyclical Markups: Theory and Evidence," American Economic Review, LXXXVI (1996), 703-725.

Coase, R., "The Nature of the Firm," Economica, IV (1937), 386-405. "The Problem of Social Cost," in The Firm, the Market, and the Law (Chicago: University of Chicago Press, 1988). pp. 95-156; article previously published in 1960 in Journal of Law and Economics, III (1960), 1-44. 
Cooley, T., and E. Prescott, "Varying Parameter Regression: A Theory and Some Applications," Annals of Economic and Social Measurement, II (1973), 463473.

Darwin, C., On the Origin of the Species by Means of Natural Selection, or the Preservation of Favoured Races in the Struggle for Life (1859).

Debreu, G., The Theory of Value (New York, NY: John Wiley and Sons, 1959).

Diamond, P., "A Model of Price Adjustment," Journal of Economic Theory, III (1971), 156-168.

Dyck, Alexander, "Privatization and Corporate Governance. Principles, Evidence, and Future Challenges," World Bank Research Observer (2000), forthcoming.

Edlin, A., and J. E. Stiglitz, "Discouraging Rivals: Managerial Rent-Seeking and Economic Inefficiencies,' American Economic Review, LXXXV (1995), 13011312.

European Corporate Governance Network, "The Separation of Ownership and Control: A Survey of 7 European Countries," Preliminary Report, Vol. 1 (Brussels: European Corporate Governance Network, 1997).

Fama, E., "Efficient Capital Markets: A Review of Theory and Empirical Work," Journal of Finance, XXV (1970), 383-417.

Fama, E., and Michael Jensen, "Separation of Ownership and Control." Journal of Law and Economics, XXVI (1983), 301-325.

Farrell, J., "Information and the Coase Theorem," Journal of Economic Perspectives, I (1987), 113-129.

Fazzari, S., R. G. Hubbard, and B. Petersen, "Financing Constraints and Corporate Investment." Brookings Papers on Economic Activity, 1 (1988a), 141-195.

Fazzari, S., R. G. Hubbard, and B. Petersen, "Investment, Financing Decisions, and Tax Policy," American Economic Review, LXXVIII (1988b), 200-205.

Fudenberg, D., and D. Levine, "Learning in Games," European Economic Review, XLII (1998a), 631-639.

Fudenberg, D., and D. Levine, The Theory of Learning in Games. MIT Press Series on Economic Learning and Social Evolution, Vol. 2 (Cambridge, MA: MIT Press, 1998b).

Furman, Jason and J. E. Stiglitz, "Economic Crises: Evidence and Insights from East Asia," Brookings Papers on Economic Activity, 2 (1999), 1-114.

Gertler, Mark, and Simon Gilchrist, "Monetary Policy, Business Cycles, and the Behavior of Small Manufacturing Firms," Quarterly Journal of Economics, CIX (1994), 309-340.

Gertler, Mark, and R. Glenn Hubbard, "Financial Factors in Business Fluctuations," in Financial Market Volatility (Federal Reserve Bank of Kansas City, 1988), pp. 33-71.

Gibbons, Robert, "Incentives in Organizations," Journal of Economic Perspectives, XII (1998), 115-132.

Gilchrist, Simon, and Egon Zakrajsek, "The Importance of Credit for Macroeconomic Activity: Identification through Heterogeneity," in Is Bank Lending Important for the Transmission of Monetary Policy?' (Boston, MA: Federal Reserve Bank of Boston, 1995), pp. 129-158.

Gould, Stephen Jay, Wonderful Life: The Burgess Shale and the Nature of History (New York: W. W. Norton, 1989).

Greenwald, B., M. Salinger, and J. E. Stiglitz, "Imperfect Capital Markets and Productivity Growth," Paper presented at NBER Conference in Vail, Colorado, April, revised March 1991 and April 1992, 1990.

Greenwald, B., and J. E. Stiglitz, "Externalities in Economies with Imperfect Information and Incomplete Markets," Quarterly Journal of Economics, CI (1986), 229-264.

Greenwald, B., and J. E. Stiglitz, "Imperfect Information, Credit Markets and Unemployment,” European Economic Review, XXXI (1987), 444-456.

Greenwald, B., and J. E. Stiglitz, "Pareto Inefficiency of Market Economies: Search and Efficiency Wage Models," American Economic Review, LXXVIII (1988), $351-355$.

Greenwald, B., and J. E. Stiglitz, "Toward a Theory of Rigidities," American Economic Review, LXXIX (1989), 364-369.

Greenwald, B., and J. E. Stiglitz, "Asymmetric Information and the New Theory of the Firm: Financial Constraints and Risk Behavior," American Economic Review, LXXX (1990), 160-165. 
Greenwald, B., and J. Stiglitz, "Financial Market Imperfections and Business Cycles," Quarterly Journal of Economics, CVIII (1993), 77-114.

Greenwald, B., and J. Stiglitz, "Labor Market Adjustments and the Persistence of Unemployment," American Economic Review, LXXXV (1995), 219-225.

Greenwald, B., J. E. Stiglitz, and A. Weiss, "Informational Imperfections in the Capital Markets and Macroeconomic Fluctuations," American Economic Review, LXXIV (1984), 194-199.

Grossman, Sanford J., "The Existence of Futures Markets, Noisy Rational Expectations and Informational Externalities," in Symposium on Economics of Information, Review of Economic Studies, XLIV (1977), 431-449.

Grossman, Sanford, and Oliver Hart, "Takeover Bids, the Free-Rider Problem, and the Theory of the Corporation," in Michael Brennan, ed., The Theory of Corporate Finance, Vol. 2 (Cheltenham, UK: Elgar, 1996), 423-445.

Grossman, S., and J. E. Stiglitz, "Information and Competitive Price Systems," American Economic Review, LXVI (1976), 246-253.

Grossman, S., and J. E. Stiglitz, "On the Impossibility of Informationally Efficient Markets," American Economic Review, LXX (1980), 393-408.

Groves, T., and J. Ledyard, "Optimal Allocation of Public Goods: A Solution to the Free-Rider Problem," Econometrica, XLV (1977), 783-809.

Hall, Bronwyn, "Investment and Research and Development at the Firm Level: Does the Source of Financing Matter?" National Bureau of Economic Research Working Paper No. 4096, June 1992.

Hall, R. E., and D. W. Jorgenson, "Tax Policy and Investment Behavior," American Economic Review, LVII (1967), 391-414.

Hannaway, Jane, "Higher Order Skills, Job Design, and Incentives: An Analysis and Proposal," American Educational Research Journal, XXIX (1992), 3-21.

Hayek, F. A., "The Use of Knowledge in Society," American Economic Review, XXXV (1945), 519-530.

Hirshleifer, J., "The Private and Social Value of Information and the Reward to Inventive Activity," American Economic Review, LXI (1971), 561-574.

Hoff, Karla, "The Second Theorem of the Second Best," Journal of Public Economics, LIV (1994), 223-242.

Hoff, K., A. Braverman, and J. E. Stiglitz, eds., The Economics of Rural Organization: Theory, Practice, and Policy (New York: Oxford University Press, 1993).

Holland, J. H., Adaptation in Natural and Artificial Systems (Cambridge, MA: MIT Press, 1975).

Hubbard, R. Glenn, "Capital-Market Imperfections and Investment," Journal of Economic Literature, XXXVI (1998), 193-225.

Hurwicz, L., "Optimality and Informational Efficiency in Resource Allocation Processes," in K. J. Arrow, S. Karlin, and P. Suppes, eds., Mathematical Methods in the Social Sciences (Stanford, CA: Stanford University Press, 1960).

Jensen, M. C., "Eclipse of the Public Corporation," in D. A. Oesterle, ed., The Law of Mergers, Acquisitions, and Reorganizations (St. Paul, MN: West, 1991).

Jensen, M., and W. Meckling, "Theory of the Firm: Managerial Behavior, Agency Costs and Ownership Structure," in J. Michael Brennan, ed., The Theory of Corporate Finance. Vol. 1 (Cheltenham, UK: Elgar, 1996), pp. 35-90; previously published in 1976 .

Kashyap, A., O. Lamont, and J. Stein, "Credit Conditions and the Cyclical Behavior of Inventories," Quarterly Journal of Economics, CIX (1994), 565592.

Kashyap, Anil, and Jeremy Stein, "What Do a Million Observations on Banks Say about the Transmission of Monetary Policy?" American Economic Review (2000), forthcoming.

Keeton, W., Equilibrium Credit Rationing (New York: Garland Press, 1979).

Kester, Carl, "Banks in the Boardroom: Germany, Japan, and the United States," in S. Hayes III, ed., Financial Services: Perspectives and Challenges (Boston: Harvard Business School Press, 1993).

King, Robert, and Ross Levine, "Finance and Growth: Schumpeter Might Be Right," Quarterly Journal of Economics, CVIII (1993), 717-737.

Klein, B., and K. Leffler, "The Role of Market Forces in Assuring Contractual Performance," Journal of Political Economy, XCIX (1981), 615-641. 
Klemperer, Paul, "Auction Theory: A Guide to the Literature," Journal of Economic Surveys, XIII (1999), 227-286.

Kohn, Alfie, Punished by Rewards (New York: Houghton Mifflin, 1993).

La Porta, R., F. Lopez-de-Silanes, A. Shleifer, and R. Vishny, "Law and Finance," Journal of Political Economy, CVI (1998), 1113-1155.

Lamont, Owen, "Cash Flow and Investment: Evidence from Internal Capital Markets," Journal of Finance, LII (1997), 83-109.

Lane, D., "Artificial Worlds and Economics, Part I," Journal of Evolutionary Economics, III (1993a), 89-107.

, "Artificial Worlds and Economics, Part II," Journal of Evolutionary Economics, III (1993b), 177-197.

Leibenstein, Harvey, Economic Backwardness and Economic Growth (New York, NY: Wiley, 1957).

Lucas, Robert, Jr., "An Equilibrium Model of the Business Cycle," Journal of Political Economy, LXXXIII (1975), 1113-1144.

Lucas, R., and E. Prescott, "Investment under Uncertainty," Econometrica, XXXIX (1971), 659-681.

Macey, Jonathan, "Institutional Investors and Corporate Monitoring: A DemandSide Perspective in a Comparative View," in Hopt et al., eds., Comparative Corporate Governance: The State of the Art and Emerging Research (Oxford: Clarendon Press, 1998).

Mailath, G., "Introduction: Symposium on Evolutionary Game Theory," Journal of Economic Theory, LVII (1992), 259-277.

Mankiw, N. G., "Small Menu Costs and Large Business Cycles: A Macroeconomic Model of Monopoly," Quarterly Journal of Economics, C (1985), 529-537.

Marschak, Jacob, "Economics of Information Systems," Journal of the American Statistical Association, LXVI (1971), 192-219.

Marshall, Alfred, Principles of Economics (London: Macmillan, 1928).

Mayer, C., "Financial Systems, Corporate Finance, and Economic Development," in R. G. Hubbard, ed., Asymmetric Information, Corporate Finance, and Investment (Chicago: University of Chicago Press, 1990), pp. 307-332.

Meyer, John, and Edwin Kuh, The Investment Decision: An Empirical Study (Cambridge, MA: Harvard University Press, 1957).

Milgrom, Paul, and John Roberts, Economics, Organization, and Management (Englewood Cliffs, NJ: Prentice-Hall, 1992).

Mill, J. S., Principles of Political Economy (London: J. P. Parker, 1848).

Mirowski, P., and K. Somefun, "Fecund, Cheap and out of Control: Heterogeneous Agents as Flawed Computers vs. Markets as Evolving Computational Entities," in M. Gallegati and A. Kirman, eds., Proceedings from a Conference on Heterogeneous Interacting Agents (Cambridge, UK: Cambridge University Press, 2000, forthcoming).

Mirrlees, J., "An Exploration in the Theory of Optimal Income Taxation," Review of Economic Studies, LXI (1971), 261-278.

"Taxing Uncertain Incomes," Oxford Economic Papers, XLII (1990), 34-45.

Modigliani, F., and M. H. Miller, "The Cost of Capital, Corporation Finance, and the Theory of Investment," American Economic Review, XLVIII (1958), 261-297.

Morduch, J., "The Microfinance Promise," unpublished paper, Hoover Institution, Stanford University, August 22, 1998.

Myers, Stewart C., and Nicholas Majluf, "Corporate Financing and Investment Decisions When Firms Have Information that Investors Do not Have," in Michael J. Brennan, ed., The Theory of Corporate Finance Vol. 1, Elgar Reference Collection (Cheltenham, U.K.: Elgar, 1996), pp. 207-241, previously published in 1984.

Nalebuff, B., and J. E. Stiglitz, "Information, Competition and Markets," American Economic Review, LXXIII (1983), 278-284.

Nelson, R., and S. Winter, "Simulation of Schumpeterian Competition," American Economic Review, LXVII (1977), 271-276.

Nelson, R., and S. Winter, An Evolutionary Theory of Economic Change (Cambridge, MA: Belknap Press of Harvard University Press, 1982).

Nelson, R., and S. Winter, "Neoclassical vs. Evolutionary Theories of Economic Growth: Critique and Prospectus," in The Economics of Innovation, Chris- 
topher Freeman, ed., International Library of Critical Writings in Economics, No. 2 (Brookfield, VT: Elgar, 1990), pp. 3-22.

Newbery, D., and J. E. Stiglitz, "Pareto Inferior Trade," Review of Economic Studies, LI (1984), 1-12.

Oliner, Stephen, and Glenn Rudebusch, "Is There a Broad Credit Channel for Monetary Policy?" Federal Reserve Bank of San Francisco Economic Review, I (1996), 3-13.

Phelps, Edmund, and Sidney Winter, "Optimal Price Policy under Atomistic Competition," in E. Phelps, ed., Microeconomic Foundations of Employment and Inflation Theory (New York: W. W. Norton, 1970), pp. 309-337.

Phillips, Gordon, "Increased Debt and Industry Product Markets: An Empirical Analysis," Journal of Financial Economics, XXXVII (1995), 189-238.

Pigou, Arthur Cecil, The Economics of Welfare (London: Macmillan and co., 1920).

Pitt, M., and S. Khandker, "The Impact of Group-Based Credit Programs on Poor Households in Bangladesh: Does the Gender of Participants Matter?" Journal of Political Economy, CVI (1998a), 958-996.

Pitt, M., and S. Khandker, "Credit Programs for the Poor and Seasonality in Rural Bangladesh,” Brown University and World Bank, draft, January 9, 1998b.

Radner, Roy, "Competitive Equilibrium under Uncertainty," Econometrica, XXXVI (1968), 31-58.

Radner, Roy, and Joseph E. Stiglitz, "A Non-Convexity in the Value of Information," in M. Boyer and R. Kihlstrom, eds., Bayesian Models in Economic Theory: Studies in Bayesian Econometrics, Vol. 5 (New York: Elsevier Science, 1984).

Raiffa, Howard, and Robert Schlaifer, Applied Statistical Decision Theory (Boston: Harvard Business School, 1961).

Ramsey, Frank P., "A Contribution to the Theory of Taxation," Economic Journal, XXXVII (1927), 47-61.

Riley, John G., "Competitive Signalling," Journal of Economic Theory, X (1975), 174-186.

"Informational Equilibrium," Econometrica, XLVII (1979), 331-360.

Robinson, Joan, The Economics of Imperfect Competition (London: Macmillan, 1933).

Rodrik, Dani, and Andrés Velasco, "Short-Term Capital Flows," Paper prepared for the 1999 ABCDE Conference at the World Bank, April 28-30, Washington, DC.

Rosenstein-Rodan, P., "Natura Facit Saltum: Analysis of the Disequilibrium Growth Process," in G. Meier and D. Seers, eds., Pioneers in Development (New York: Oxford University Press for the World Bank, 1984).

Ross, S., "The Economic Theory of Agency: The Principal's Problem," American Economic Review, LXIII (1973), 134-139.

"The Determination of Financial Structures: The Incentive Signaling Approach," Bell Journal of Economics, VIII (1977), 23-40.

Rothschild, M., and J. E. Stiglitz, "Equilibrium in Competitive Insurance Markets: An Essay on the Economics of Imperfect Information," Quarterly Journal of Economics, XC (1976), 629-649.

Rothschild, M., and J. E. Stiglitz, "Competition and Insurance Twenty Years Later." Geneva Papers on Risk and Insurance Theory, XXII (1997), 73-79.

Salop, Steven, "The Noisy Monopolist: Imperfect Information, Price Dispersion and Price Discrimination," in Symposium on Economics of Information, Review of Economic Studies, XLIV (1977), 393-406.

Salop, S., and J. E. Stiglitz, "Bargains and Ripoffs: A Model of Monopolistically Competitive Price Dispersions," Review of Economic Studies, XLIV (1977), 493-510.

Salop, S., and J. E. Stiglitz, "The Theory of Sales: A Simple Model of Equilibrium Price Dispersion with Identical Agents," American Economic Review, LXXII (1982), 1121-1130.

Samuelson, P. Foundations of Economic Analysis (Cambridge, MA: Harvard University Press, 1947).

Shaban, Radwan Ali, "Testing between Competing Models of Sharecropping," Journal of Political Economy, XCV (1987), 893-920.

Shapiro, C., "Premiums for High Quality Products as Returns to Reputations," Quarterly Journal of Economics, XCVIII (1983), 658-679. 
Shapiro, C., and J. E. Stiglitz, "Equilibrium Unemployment as a Worker Discipline Device," American Economic Review, LXXIV (1984), 433-444.

Shleifer, Andrei, and Robert W. Vishny, "Value Maximization and the Acquisition Process," Journal of Economic Perspectives, II (1988), 7-20.

Shleifer, Andrei, and Robert W. Vishny, "Management Entrenchment: The Case of Manager-Specific Investments, Journal of Financial Economics, XXV (1989), 123-139.

Shleifer, Andrei, and Robert W. Vishny, "A Survey of Corporate Governance," Journal of Finance, LII (1997), 737-783.

Shleifer, Andrei, and Robert W. Vishny, The Grabbing Hand: Government Pathologies and their Cures (Cambridge, MA: Harvard University Press, 1998).

Sismondi, Simonde De, Political Economy (New York: Kelley, 1966 [1814]).

Smith, A., An Inquiry into the Nature and Causes of the Wealth of Nations, E. Cannan, ed. (London: Methuen, 1904 [1776]).

Spence, Michael, Market Signaling: Information Transfer in Hiring and Related Processes (Cambridge, MA: Harvard University Press, 1974).

Stigler, George J., "The Economics of Information," Journal of Political Economy, LXIX (1961), 213-225.

"Imperfections in the Capital Market," Journal of Political Economy, LXXV (1967), 287-292.

Stiglitz, Joseph E., "On the Optimality of the Stock Market Allocation of Investment," Quarterly Journal of Economics, LXXXVI (1972), 25-60.

"Incentives and Risk Sharing in Sharecropping," Review of Economic Studies, XLI (1974), 219-255.

"The Theory of Screening, Education and the Distribution of Income," American Economic Review, LXV (1975), 283-300.

"The Inefficiency of the Stock Market Equilibrium," Review of Economic Studies, XLIX (1982a), 241-261.

"Information and Capital Markets," in William F. Sharpe and Cathryn Cootner, eds., Financial Economics: Essays in Honor of Paul Cootner (Englewood Cliffs, NJ: Prentice-Hall, 1982b), pp. 118-158.

"Equilibrium Wage Distributions," Economic Journal, XCV (1985a), 595618.

"Credit Markets and the Control of Capital," Journal of Money, Credit and Banking, XVII (1985b), 133-152.

"The Causes and Consequences of the Dependence of Quality on Prices," Journal of Economic Literature, XXV (1987), 1-48.

"Competition and the Number of Firms in a Market: Are Duopolies More Competitive Than Atomistic Markets?" Journal of Political Economy, XCV (1987), 1041-1061.

Stiglitz, J. E., and A. Weiss, "Credit Rationing in Markets with Imperfect Information," American Economic Review, LXXI (1981), 393-410.

Townsend, Robert, "Optimal Contracts and Competitive Markets with Costly State Verification," Journal of Economic Theory, XXI (1979), 265-293.

van Damme, E., Stability and Perfection of Nash Equilibria (Berlin: Springer Verlag, 1987).

Varian, H., "A Model of Sales," American Economic Review, LXX (1980), 651-659.

Vickrey, William, "Auctions and Bidding Games," in Richard Arnott et al., eds., Public Economics: Selected Papers by William Vickrey (New York and Melbourne: Cambridge University Press, 1994), pp. 85-98; reprinted from Recent Advances in Game Theory (Princeton, NJ: Princeton University Press, 1962). "Counterspeculation, Auctions, and Competitive Sealed Tenders," in David Levine and Steven Lippman, eds., The Economics of Information, Vol. 1 (Aldershot, UK: Elgar, 1995), pp. 15-44.

Weber, Max, The Protestant Ethic and the Spirit of Capitalism (New York: Scribner, 1925).

Weibull, J. W., Evolutionary Game Theory (Cambridge, MA: MIT Press, 1996).

Weiss, Andrew, "Human Capital vs. Signalling Explanations of Wages," Journal of Economic Perspectives, IX (1995), 133-154.

Weiss, Andrew, and Georgiy Nikitin, Performance of Czech Companies by Ownership Structure (Washington, DC: World Bank, 1998).

Williamson, Oliver E., "Transactions-Cost Economics: The Governance of Contractual Relations," Journal of Law and Economics, XXII (1979), 233-261. 
The Economic Institutions of Capitalism (New York: The Free Press, 1985).

Wojnilower, Albert, "The Central Role of Credit Crunches in Recent Financial History," Brookings Papers on Economic Activity, 2 (1980), 277-326.

World Bank, World Development Report 1996: From Plan to Market (Washington, DC: World Bank, 1996).

Global Economic Prospects and the Developing Countries 1998/1999: Beyond Financial Crisis (Washington, DC: World Bank, 1998).

, Global Economic Prospects and the Developing Countries 2000 (Washington,

DC: World Bank, 1999).

Zaman, H., "Who Benefits and to What Extent? An Evaluation of BRAC's Micro-credit Program," D.Phil thesis, University of Sussex, 1998.

Zingales, Luigi, "The Value of the Voting Right: A Study of the Milan Stock Exchange Experience," Review of Financial Studies, VII (1994), 125-148. 